\section{Two Distinct Forms of Factor VIII Coagulant Protein in Human Plasma Cleavage by Thrombin, and Differences in Coagulant Activity and Association with von Willebrand Factor}

Mark J. Weinstein and Leslie E. Chute Hematology-Hemostasis Section, Research Service, Boston Veterans Administration Medical Center, Department of Biochemistry, Boston University School of Medicine, Boston, Massachusetts 02130 bstract. We have characterized Factor VIII coagulant protein, present in normal human plasma, that reacts with a specific human ${ }^{125}$ I-labeled anti-human VIII:C antigen Fab antibody fragment. Two major Factor VIII coagulant antigen populations were present. The first, $\sim 85 \%$ of the total antigen, was bound to von Willebrand factor and when tested in a standard one-stage assay had Factor VIII coagulant activity. The second antigenic population, eluting near fibrinogen when plasma was gel filtered, was not bound to von Willebrand protein, did not have Factor VIII coagulant activity unless activated, but did block anti-VIII:C Fab neutralization of clotting activity. The two antigenic populations were separable by cryoprecipitation and agarose gel electrophoresis.

Although the two antigenic populations differed in their Factor VIII coagulant activity and in their binding to von Willebrand factor, the principal member of both populations is of mol wt $2.4 \times 10^{5}$. Both antigens, when proteolyzed by thrombin, were quickly converted to a $1 \times 10^{5}-\mathrm{mol} w t$ form in association with the appearance of VIII:C activity. The $1 \times 10^{5}$-mol wt antigen was further slowly degraded to an $8 \times 10^{4}$-mol wt form while Factor VIII coagulant activity declined. These results demonstrate the presence of an inactive Factor VIII coagulant protein in plasma, not associated with von Willebrand

A preliminary report was presented at the 23rd Annual Meeting of the American Society of Hematology, San Antonio, TX, December, 1981. Address correspondence to Dr. Weinstein, Boston City Hospital, Boston, MA 02118. 1983.

Received for publication 18 May 1982 and in revised form 17 October

The Journal of Clinical Investigation, Inc.

Volume 73, February 1984, 307-316 factor, that can react with thrombin to yield Factor VIII coagulant activity.

\section{Introduction}

Factor VIII:C (VIII:C) ${ }^{1}$ (antihemophilic factor) plays a central role in the intrinsic blood coagulation pathway, acting as a cofactor in the reaction between Factors' IX and X. Most Factor VIII coagulant protein, under normal physiological conditions, is associated with $(1,2)$ but distinct from von Willebrand factor (vWF), a high molecular weight multimeric protein necessary for optimal binding of platelets to the subendothelium (3). Despite the importance of Factor VIII in hemostasis, little is known about the structure of the protein in plasma. Difficulties in its purification caused by low plasma concentration (4) and extreme susceptibility to proteolysis (5-7) by thrombin and other enzymes have hampered its characterization.

One approach to studying Factor VIII coagulant protein with a minimum of purification is as an antigen (VIII:CAg), through the use of ${ }^{125}$ I-labeled anti-VIII:C Fab $\left({ }^{125} \mathrm{I}\right.$-Fab) $(8,9)$. This reagent, obtained from the plasma of a multiply transfused hemophilic patient with a high titer anti-VIII:C antibody, was specific for VIII:C-related protein, as measured by its ability to inhibit VIII:C activity and its nonreactivity with plasma from patients with severe hemophilia. ${ }^{125} \mathrm{I}-\mathrm{Fab}$, when incubated with normal plasma, formed stable 1:1 stoichiometric complexes with VIII:CAg, which are resistant to urea-sodium dodecyl sulfate (SDS) denaturation at $37^{\circ} \mathrm{C}$. This urea-SDS treatment was sufficient, however, to dissociate VIII:CAg from vWF. The elec-

1. Abbreviations used in this paper: DFP, diisopropylfluorophosphate; VIII:C, Factor VIII:C; VIII:CAg, Factor VIII coagulant antigen; VIII:RAg, Factor VIII related antigen; ${ }^{125} \mathrm{I}-\mathrm{Fab},{ }^{125} \mathrm{I}$-labeled Fab prepared from human anti-VIII:C IgG; KIU, kallikrein inhibitor units; NIH, National Institutes of Health; PAAGE, polyacrylamide agarose gel electrophoresis; p-APMSF, ( $p$-amidinophenyl) methanesulfonyl fluoride; PEG, polyethylene glycol; VBS, $0.125 \mathrm{M} \mathrm{NaCl-0.028} \mathrm{M}$ sodium barbital, pH 7.35; $\mathrm{V}_{\mathrm{i}}$, included volume; $\mathrm{V}_{0}$, void volume; vWF, von Willebrand Factor. 
trophoretic mobility of ${ }^{125} \mathrm{I}-\mathrm{Fab}-\mathrm{VIII}: \mathrm{CAg}$ complexes on SDSpolyacrylamide-agarose gels (PAAGE) was used to calculate the apparent free molecular weight of VIII:CAg.

70-80\% of VIII:CAg in whole plasma, when examined by SDS-PAAGE, had a molecular weight of $2.4 \times 10^{5}$. The remaining VIII:CAg was distributed among at least five VIII:CAg bands ranging from $0.85 \times 10^{5}$ to $2.6 \times 10^{5} \mathrm{~mol} \mathrm{wt} \mathrm{(8)}$. The epitope site remained intact after thrombin proteolysis, yielding VIII:CAg forms of 1 and $0.8 \times 10^{5} \mathrm{~mol} w t$.

In contrast to this result with urea-SDS, two major VIII:CAg populations are present when normal plasma, incubated with ${ }^{125} \mathrm{I}-\mathrm{Fab}$, is gel filtered over agarose under nondenaturing conditions (9). The first VIII:CAg peak is in the void volume $\left(\mathrm{V}_{0}\right)$ fraction along with VIII:C coagulant activity and vWF. The second antigenic fraction is near the fibrinogen peak in a region without VIII:C activity. Considering the susceptibility of VIII:CAg to proteolysis, this second antigen peak could be composed of inactivated VIII:CAg fragments. Alternatively, since VIII:C activity can be dissociated from vWF in the presence of high ionic strength buffers $(2,10)$, indicating association by noncovalent bonds, the second antigenic peak might contain VIII:C protein in equilibrium with that bound to vWF.

To characterize further these two antigenic populations obtained under nondenaturing conditions, we have determined their apparent molecular weight by the immunological SDSPAAGE procedure. We have also examined the molecular weight changes in both populations after thrombin treatment, the association of antigenic fragments with vWF, and the correlation of antigenic forms with VIII:C activity.

\section{Methods}

Plasma preparation. Venous blood ( 9 vol) collected by a two-syringe technique, was anticoagulated with $3.8 \%$ sodium citrate, 90 National Institutes of Health (NIH) U/ml hirudin (Sigma Chemical Co., St. Louis, $\mathrm{MO}$ ), and 100 kallikrein inhibitor units (KIU)/ml Trasylol (Mobay Chemical Corp., FBA Pharmaceuticals, New York) (1 vol). Plateletpoor plasma was separated by centrifuging twice at $4,000 \mathrm{~g}$ for $3 \mathrm{~min}$ $\left(22^{\circ} \mathrm{C}\right)$. Plasma samples either were used immediately or stored at $-70^{\circ} \mathrm{C}$ for subsequent analysis. Pooled normal plasma from 14 individuals was prepared in citrate without added inhibitors.

Assays of Factor VIII-related activities. VIII:C activity was measured by one-stage activated partial thromboplastin time (11) by using hemophilia A plasma as substrate (VIII:C $<1 \%$ ). $1 \mathrm{U}$ of VIII:C activity is the amount present in $1 \mathrm{ml}$ of plasma. The coagulant assay can detect VIII:C $<0.01 \mathrm{U} / \mathrm{ml}$. vWF antigen (Factor VIII-related antigen, VIII:RAg) was quantified by solid-phase immunoradiometric assay (12) with ${ }^{125}$ Ilabeled and unlabeled rabbit anti-human vWF (Dako Antibodies, Accurate Chemical and Scientific Corp., Westbury, NY). The assay can detect vWF antigen at levels $\geqq 0.0002 \mathrm{U} / \mathrm{ml}$, where $1 \mathrm{U}$ is equivalent to that present in $1 \mathrm{ml}$ of plasma.

${ }^{125} \mathrm{I}-\mathrm{Fab}$, prepared by a previously described method (13), was stored at $-70^{\circ} \mathrm{C}$ as a solution containing $2-3 \times 10^{5} \mathrm{cpm} / \mathrm{ml}$, with a sp act of $\sim 3 \times 10^{6} \mathrm{cpm} / \mu \mathrm{g}$ protein and $2 \times 10^{4} \mathrm{NIH} \mathrm{U} / \mathrm{mg}$ protein VIII:C inhibitory activity. A standard ${ }^{125}$ I-Fab-inhibitor-polyethylene glycol (PEG) solution, used to quantify VIII:CAg in a fluid-phase immunoradiometric assay and in gel electrophoretic experiments, was prepared immediately before use. It contained varying quantities of ${ }^{125} \mathrm{I}-\mathrm{Fab}, 5$ $\mathrm{mM}$ diisopropylfluorophosphate (DFP), $95 \mathrm{NIH} \mathrm{U/ml} \mathrm{hirudin,} 370 \mathrm{KIU} /$ $\mathrm{ml}$ Trasylol, $2 \mu \mathrm{M}$ ( $p$-amidinophenyl) methanesulfonyl fluoride ( $p$ APMSF), a gift from Laura et al. (14) (Dr. David Bing, Center for Blood Research, Boston, MA), and 3.2\% PEG 4000 (PEG-4000, Fisher Scientific Co., Pittsburgh, PA).

In the quantitative immunoradiometric fluid-phase assay of VIII:CAg, ${ }^{125} \mathrm{I}$-Fab-inhibitor-PEG solution $(28 \mu \mathrm{l})$, containing at least $5,600 \mathrm{cpm}$, was mixed with diluted plasma or gel filtration eluate fractions $(100 \mu \mathrm{l})$. Samples were incubated for $1.5 \mathrm{~h}$ at $37^{\circ} \mathrm{C}, 0.5 \mathrm{~h}$ at $0^{\circ} \mathrm{C}$, and rewarmed to $22^{\circ} \mathrm{C}$. Aliquots $(60 \mu \mathrm{l})$ were then mixed with $10 \mathrm{mg} \mathrm{IgG} / \mathrm{ml}$ (Fraction II, Miles Laboratories Inc., Miles Research Products Division, Elkhart, IN) in $0.125 \mathrm{M} \mathrm{NaCl}-0.028 \mathrm{M}$ sodium barbital, pH 7.35 (VBS) $(60 \mu \mathrm{l})$ followed by $50 \%$ PEG- 400 in water $\left(380 \mu \mathrm{l}, 0^{\circ} \mathrm{C}\right)$. After incubation at $0^{\circ} \mathrm{C}$ for $1 \mathrm{~h}$, samples were centrifuged at $12,000 \mathrm{~g}$ for $3 \mathrm{~min}$, and decanted. Pellets were washed with $38 \%$ PEG-400 $\left(200 \mu l, 0^{\circ} \mathrm{C}\right)$, recentrifuged, and counted for $10 \mathrm{~min} / \mathrm{sample}$ to determine radioactivity. A standard curve was derived from a least squares linear regression analysis of $\log$ bound radioactivity (counts per minute) vs. log normal pool plasma dilution. The curve was linear in the range of $1.5-15 \%$ normal plasma diluted in VBS.

Gel filtration column chromatography. Normal plasma $(1 \mathrm{ml})$, containing inhibitors (see above), was gel filtered over an agarose column (A5 M, Bio-Rad Laboratories, Rockville Centre, NY, or Sepharose Cl6B, Pharmacia Fine Chemicals, Piscataway, NJ) of $0.9 \times 48 \mathrm{~cm}$, equilibrated with freshly made $0.01 \mathrm{M}$ sodium barbital, $0.015 \mathrm{M}$ barbituric acid, $0.125 \mathrm{M} \mathrm{NaCl}, 0.04 \mathrm{M} \epsilon$-amino caproic acid, $0.02 \%$ sodium azide, $10 \mathrm{KIU} / \mathrm{ml}$ Trasylol, $0.5 \mathrm{mM}$ DFP, and $1 \mathrm{mg} / \mathrm{ml}$ bovine serum albumin (BSA) (Cohn fraction V, fatty acid-free, Sigma Chemical Co.), pH 7.5. The albumin was pretreated with $N$-ethylmaleimide (15) to block free sulfhydryl groups. In some instances up to $20 \mathrm{ml}$ of plasma was chromatographed over $5 \times 35-\mathrm{cm} \mathrm{A5} \mathrm{M}$ columns with the same buffering conditions to obtain larger amounts of VIII:CAg. Column fractions were assayed immediately for VIII:C and vWF, and the various electrophoretic analyses were done thereafter.

To prepare cryoprecipitate and cryosupernatant for gel filtration chromatography, pooled plasma at $37^{\circ} \mathrm{C}$ containing $200 \mathrm{KIU} / \mathrm{ml}$ Trasylol was adjusted to $2.5 \%$ PEG-4000 from a $45 \%$ stock PEG-4000 solution in water. Samples $(1 \mathrm{ml})$ were kept at $0^{\circ} \mathrm{C}$ for $2 \mathrm{~h}$ and centrifuged at $5,000 \mathrm{~g}$ for $3 \mathrm{~min}$. Precipitates were dissolved in $1 \mathrm{ml}$ of column buffer, incubated with ${ }^{125} \mathrm{I}$-Fab $\left(1.1 \times 10^{5} \mathrm{cpm}\right.$, stock solution concentrated five times) for $2 \mathrm{~h}$ at $37^{\circ} \mathrm{C}$, and gel filtered at $22^{\circ} \mathrm{C}$. Supernatants were also incubated with ${ }^{125} \mathrm{I}-\mathrm{Fab}$ and chromatographed.

Concentration of included volume $\left(V_{i}\right)$ VIII:CAg. $\mathrm{V}_{\mathrm{i}}$ VIII:CAg, obtained from gel filtration experiments, was concentrated on DEAESephacel (Pharmacia Fine Chemicals) equilibrated with $8.6 \mathrm{mM}$ sodium barbital, $13 \mathrm{mM}$ barbituric acid, $0.1 \mathrm{M} \mathrm{NaCl}, 34 \mathrm{mM}$ e-amino caproic acid, and $0.02 \%$ sodium azide, $\mathrm{pH}$ 7.5. Typically, starting with $1 \mathrm{ml}$ normal plasma, $\sim 7 \mathrm{ml}$ of pooled gel filtrate containing 0.01-0.02 $\mathrm{U} / \mathrm{ml} \mathrm{V}$ VIII:CAg was concentrated on $1.4 \mathrm{ml}$ DEAE-Sephacel. After washing the resin with an additional $3 \mathrm{ml}$ buffer, protein was eluted with buffer adjusted to $17 \mathrm{mS}$ with $\mathrm{NaCl}$. $\mathrm{V}_{\mathrm{i}}$ VIII:CAg was concentrated five- to sevenfold with $\sim 90 \%$ recovery. Other concentration procedures included placing $\mathrm{V}_{\mathrm{i}}$ VIII:CAg-containing fractions in dialysis tubing surrounded by Aquacide (Calbiochem-Behring Corp., La Jolla, CA), or using Millipore CX-10 ultrafilters (Millipore Corp., Bedford, MA). In experiments to examine the binding of $V_{i}$ VIII:CAg to calcium-treated vWF, the $V_{i}$ VIII:CAg pool was absorbed with monoclonal anti-vWFIgG-sepharose (a gift from Dr. Theodore Zimmerman, Scripps Research Foundation, La Jolla, CA) to remove traces of contaminating vWF protein. 
Inhibitor blocking by $V_{i}$ VIII:CAg (16). The modified activated partial thromboplastin test used in this experiment consisted of incubating hemophilic plasma $(0.1 \mathrm{ml})$ at $37^{\circ} \mathrm{C}$ for $12 \mathrm{~min}$ with $0.1 \mathrm{ml} 0.1 \%$ Lecithin Centrolex P (Central Soya, Chicago, IL) in VBS plus $0.1 \mathrm{ml} 0.4 \%$ Kaolin (acid washed, Fisher Scientific Co.) in VBS. Normal plasma $(0.1 \mathrm{ml})$, diluted with VBS and mixtures of anti-VIII:C Fab or V VIII:CAg, was added to the activated hemophilic plasma solution, followed by $0.1 \mathrm{ml}$ $0.033 \mathrm{M} \mathrm{CaCl}_{2}$ to initiate clot formation.

The concentration of human anti-VIII:C Fab was adjusted with VBS so that a 1:1 mixture of antibody solution and diluted normal plasma ( 1 vol plasma in 9 vol VBS) produced, after incubation for $2 \mathrm{~h}$ at $37^{\circ} \mathrm{C}$, a 50\% reduction in VIII:C activity compared with incubation of plasma with VBS alone. Before reaction with normal plasma, 1 vol of human anti-VIII:C Fab was incubated for $2 \mathrm{~h}$ at $37^{\circ} \mathrm{C}$ with 1 vol either of VBS or concentrated $\mathrm{V}_{i}$ VIII:CAg $(0.1 \mathrm{U} / \mathrm{ml}$ VIII:CAg, dialyzed against VBS to remove excess $\mathrm{NaCl}$ ). Shortened clotting times (and increased VIII:C), which approached those obtained when plasma was incubated with VBS alone, indicated that $\mathrm{V}_{\mathrm{i}}$ VIII:CAg bound to anti-VIII:C Fab and blocked the inhibition of plasma VIII:C by anti-VIII:C Fab. In control experiments, $V_{i}$ VIII:CAg alone was added to normal plasma $2 \mathrm{~h}$ before, or simultaneously with, the initiation of clotting by calcium. Anti-VIII:C Fab was also mixed with plasma just before calcium addition.

Electrophoresis on $0.3 / 2 \%$ agarose gels. Agarose (SeaKem HGT, FMC Corp., Marine Colloids Division, Rockland, ME) (2\%) slab gels, $1.5 \times 60 \times 180 \mathrm{~mm}$, were poured in $0.081 \mathrm{M}$ Tris-0.024 M Tricine running buffer, $\mathrm{pH} 8.6 .0 .3 \%$ agarose gels, $1.5 \times 30 \times 180 \mathrm{~mm}$, were poured adjacent to the $2 \%$ gel with a well-forming comb (Bio-Rad Laboratories) and placed $1.5 \mathrm{~cm}$ from the $2 \%$ gel.

Sample aliquots ( $30 \mu \mathrm{l})$ were incubated with $33 \mu \mathrm{l}{ }^{125} \mathrm{I}$-Fab solution (at least 2,000 cpm) containing proteolytic inhibitors and PEG for 1.5 $\mathrm{h}$ at $37^{\circ} \mathrm{C}$, and then for $0.5 \mathrm{~h}$ at $0^{\circ} \mathrm{C}$. After rewarming at $23^{\circ} \mathrm{C}$ for 15 min, 30- $\mu$ l aliquots were applied to sample wells. The tracking dye, $0.1 \%$ bromphenol blue $(1.5 \mu \mathrm{l})$, was included in some samples. Gels were electrophoresed horizontally for $20 \mathrm{~min}$ at $50 \mathrm{~V}, 15 \mathrm{~min}$ at 100 $\mathrm{V}$, and $4 \mathrm{~h}$ at $150 \mathrm{~V}$. When the bromphenol blue dye reached the 0.3 / $2 \%$ gel interface, sample wells were filled with $0.3 \%$ agarose in running buffer to prevent loss of any material that may have remained in the wells. After electrophoresis, the gels were fixed in $10 \%$ acetic acid-25\% isopropanol for at least $2 \mathrm{~h}$, soaked in $10 \%$ acetic acid-2\% glycerol for 1-2 h, and finally dried with hot air under a heat lamp. The gels were placed with XAR-5 X-Omat film (Eastman Kodak Co., Rochester, NY) in film cassettes containing Chronex Lighting Plus intensifying screens (E. I. du Pont de Nemours and Co., Inc., Wilmington, DE) for 4-7 d at $-70^{\circ} \mathrm{C}$.

Association of $V_{i}$ VIII:CAg and $\mathrm{Ca}^{2+}$-treated VIII:C protein with $\mathrm{Ca}^{2+}$-treated $v W F$. To prepare $\mathrm{Ca}^{2+}$-treated vWF, $6.0 \mathrm{ml}$ of normal citrated plasma containing $1 \mathrm{mM}$ DFP and $100 \mathrm{U} / \mathrm{ml}$ Trasylol was gel filtered over a $2.5 \times 30-\mathrm{cm}$ column of Bio-Rad A5 M agarose equilibrated with VBS, $1 \mathrm{mg} / \mathrm{ml} \mathrm{BSA}, 10 \mathrm{U} / \mathrm{ml}$ Trasylol, and $1 \mathrm{mM}$ DFP. The $\mathrm{V}_{0}$ fractions from three columns were combined and mixed with human $\mathrm{IgG}, 1 \mathrm{mg} / \mathrm{ml}$ final concentration. The IgG, in a stock solution of 100 $\mathrm{mg} / \mathrm{ml} \mathrm{VBS}$ heated to $56^{\circ} \mathrm{C}$ for $30 \mathrm{~min}$ before use, acted as a carrier protein to aid in precipitation.

Protein in the $\mathrm{V}_{0}$ fraction was precipitated with PEG-400, 38\% final concentration, at $0^{\circ} \mathrm{C}$ for $1.5 \mathrm{~h}$. After centrifuging the solution at 12,000 $g$ for $10 \mathrm{~min}$, the precipitate was dissolved in $2.0 \mathrm{ml} / \mathrm{VBS}, 0.2 \mathrm{mg} / \mathrm{ml}$ BSA, and $10 \mathrm{U} / \mathrm{ml}$ Trasylol. To separate $\mathrm{V}_{0}$ VIII:CAg from vWF, the dialyzed $\mathrm{V}_{0}$ solution was adjusted to $0.25 \mathrm{M} \mathrm{CaCl}_{2}$, incubated at $37^{\circ} \mathrm{C}$ for $1 \mathrm{~h}$, and gel filtered on a $1.6 \times 50-\mathrm{cm}$ column of Fractogel TSK HW-75(F) (Pierce Chemical Co., Rockford, IL). The column was buffered in $1 \mathrm{mM}$ benzamidine $\mathrm{HCl}, 0.01 \mathrm{mg} / \mathrm{ml}$ soybean trypsin inhibitor, 10
$\mathrm{U} / \mathrm{ml}$ Trasylol, $0.2 \mathrm{mg} / \mathrm{ml} \mathrm{BSA}, 0.25 \mathrm{M} \mathrm{CaCl}_{2}, 0.02 \%$ sodium azide, and $0.05 \mathrm{M}$ imidazole, $\mathrm{pH}$ 6.8. Column fractions were assayed for VIII:C activity and for vWF by immunoelectrophoresis. Those with vWF but no VIII:C were pooled, concentrated against Aquacide, and dialyzed against VBS containing $10 \mathrm{U} / \mathrm{ml}$ Trasylol- $3 \mathrm{mM} \mathrm{CaCl}_{2}$. Eluate fractions containing $\mathrm{Ca}^{2+}$-dissociated VIII:C were similarly concentrated and dialyzed.

To determine if $\mathrm{V}_{\mathrm{i}}$ VIII:CAg associates with $\mathrm{vWF}$ protein, $\mathrm{Ca}^{2+}$. treated vWF $(0.25 \mathrm{ml}, 0.44 \mathrm{U} / \mathrm{ml})$ was incubated $\left(37^{\circ} \mathrm{C}, 2 \mathrm{~h}\right)$ with 0.25 $\mathrm{ml} \mathrm{V}$ VIII:CAg (0.5 U/ml) in VBS containing $2 \mathrm{mM}$ DFP, $48 \mathrm{U} / \mathrm{ml}$ hirudin, $180 \mathrm{U} / \mathrm{ml}$ Trasylol, $1 \mu \mathrm{M} p \mathrm{APMSF}$, and $3 \mathrm{mM} \mathrm{CaCl}$. After an additional incubation with $0.25 \mathrm{ml}{ }^{125} \mathrm{I}-\mathrm{Fab}\left(5 \times 10^{4} \mathrm{cpm}\right)$ plus $2 \%$ PEG-4000 at final concentration for $2 \mathrm{~h}$ at $37^{\circ} \mathrm{C}$, the solution was gel filtered over a $0.9 \times 47-\mathrm{cm}$ A5 M column equilibrated with VBS, 0.2 $\mathrm{mg} / \mathrm{ml} \mathrm{BSA}, 0.5 \mathrm{mM}$ DFP, and $3 \mathrm{mM} \mathrm{CaCl}_{2}$. Column fractions were examined for radioactivity and $\mathrm{VWF}$ protein. Control experiments included gel chromatography of ${ }^{125} \mathrm{I}-\mathrm{Fab}$ plus $\mathrm{Ca}^{2+}$-treated vWF.

The $\mathrm{Ca}^{2+}$-dissociated VIII:C protein was treated similarly to $\mathrm{V}_{i}$ VIII:CAg to see if it would recombine with vWF. A $0.25-\mathrm{ml}$ aliquot of $\mathrm{Ca}^{2+}$-dissociated VIII:C (0.5 U/ml VIII:CAg) was incubated with $\mathrm{Ca}^{2+}$ treated vWF $(0.25 \mathrm{ml}, 0.53 \mathrm{U} / \mathrm{ml})$, incubated with ${ }^{125} \mathrm{I}-\mathrm{Fab}\left(5.5 \times 10^{4}\right)$, and chromatographed over A5 M at $0.9 \times 45 \mathrm{~cm}$ (see above). As a control, $\mathrm{Ca}^{2+}$-dissociated VIII:C plus ${ }^{125} \mathrm{I}-\mathrm{Fab}$ was also gel filtered.

SDS-3\% and $4 \%$ polyacrylamide-0.5\% agarose gel electrophoresis (SDS-3\% or 4\% PAAGE). Slab gels were formed with a final concentration of either 3 or $4 \%$ polyacrylamide $/ 0.5 \%$ agarose on a backing of Gel Bond (FMC Corp.) (9). Samples containing VIII:CAg and ${ }^{125}$ I-Fab (see below) were mixed with an equal volume of $0.02 \mathrm{M}$ Tris $\mathrm{HCl}, 2 \mathrm{mM}$ EDTA, $8 \mathrm{M}$ urea, and 2\% SDS, pH 8.0. After incubation for $20 \mathrm{~min}$ at $37^{\circ} \mathrm{C}, 30-\mu \mathrm{l}$ aliquots were applied to the gels. Electrophoresis was at $30 \mathrm{~V}$ for $20 \mathrm{~min}, 70 \mathrm{~V}$ for $15 \mathrm{~min}$, and $125 \mathrm{~V}$ for $135 \mathrm{~min}$ (3\% polyacrylamide) or $195 \mathrm{~min}$ (4\% polyacrylamide). The same fixing and autoradiographic development procedures were used as for the $0.3 / 2 \%$ agarose gels, except that the gels were dried in a $56^{\circ} \mathrm{C}$ oven for $6 \mathrm{~h}$ rather than under a heat lamp. Autoradiographic patterns were quantified by densitometry.

Thrombin treatment of VIII:CAg and analysis by electrophoretic procedures. The peak $\mathrm{V}_{0}$ eluate fractions $(\sim 1 \mathrm{ml})$ of gel filtered plasma (see above) containing the highest level of VIII:C was used for thrombin digestion experiments. $V_{0}$ samples were incubated with $100 \mathrm{KIU} / \mathrm{ml}$ Trasylol for $20 \mathrm{~min}$ at $23^{\circ} \mathrm{C}$ before thrombin addition.

Thrombin (sp act 2,500 U/mg, $0.05 \mathrm{U} / \mathrm{ml}$ final concentration), kindly provided by Dr. John Fenton II (New York State Department of Health, Albany, NY), was added at $23^{\circ} \mathrm{C}$ to an aliquot $(0.75 \mathrm{ml})$ of the $\mathrm{V}_{0}$ fraction. At various time points, $25-\mu 1$ samples were withdrawn, diluted 20-fold, and assayed for VIII:C. At each time point two additional samples were withdrawn: $60 \mu \mathrm{l}$ for immunoelectrophoresis and $0.3 \%$ agarose gels, and $25 \mu \mathrm{l}$ for SDS-4\% PAAGE. A sample $(0.12 \mathrm{ml})$ of the $\mathrm{V}_{0}$ solution, untreated with thrombin, was set aside to be used for assays of the zero-time point. An additional aliquot $(0.12 \mathrm{ml})$ of the $\mathrm{V}_{0}$ fraction was incubated either with 0.5 or $1 \mathrm{U} / \mathrm{ml}$ thrombin for $15 \mathrm{~min}$, then assayed for VIII-related activities.

Before immunoelectrophoresis and electrophoresis on $0.3 \%$ agarose gels, the $60-\mu 1$ aliquots were treated with ${ }^{125}$ I-Fab solution containing inhibitors and PEG under the same conditions as samples prepared for $0.3 / 2 \%$ agarose electrophoresis.

Similarly, the $25-\mu 1$ aliquots for SDS-PAAGE were incubated with $27 \mu{ }^{125}$ I-Fab solution containing inhibitors and PEG, but the samples were then incubated with an equal volume of SDS-urea denaturing buffer, and 30- $\mu$ l aliquots were analyzed by SDS-4\% PAAGE.

The same thrombin activation and sampling procedures were used 
to examine DEAE-concentrated $V_{i}$ VIII:CAg. The $V_{i}$ fraction, however, was rich in fibrinogen. The fibrin clot formed with the addition of thrombin could interfere with sample withdrawal. To circumvent this, the polypeptide Gly-Pro-Arg-Pro, (kindly provided by Dr. Russell Doolittle, University of California San Diego, La Jolla, CA), $5 \mathrm{mM}$ final concentration, was added to the $V_{i}$ VIII:CAg fraction to prevent fibrin monomer aggregation (17). This concentration of polypeptide did not affect the VIII:C assay, since reaction mixtures were diluted 20-fold before testing.

Immunoelectrophoretic detection of ${ }^{125}$ I-Fab-VIII:CAg associated with $v W F$. Samples of the $\mathrm{V}_{0}$ gel filtration fraction, obtained before and after treatment with thrombin, were placed on $0.5 \%$ SeaKem agarose (FMC Corp., Marine Colloids Div.) in a gel buffer of $0.016 \mathrm{M}$ sodium barbital$0.027 \mathrm{M}$ sodium acetate, $\mathrm{pH}$ 8.6. This gel $(1.5 \times 60 \times 185 \mathrm{~mm})$ also contained 1/200 (vol/vol) anti-VIII:RAg antiserum (Calbiochem Behring Corp.). Samples $(25 \mu \mathrm{l})$, incubated with ${ }^{125}$ I-Fab, were electrophoresed for $18 \mathrm{~h}, 20 \mathrm{~mA}$ constant current, using a running buffer threefold more concentrated than the gel buffer. The gel was then soaked in $0.15 \mathrm{M}$ $\mathrm{NaCl}$ for $24 \mathrm{~h}$, washed two times in water, pressed, dried, and stained with Coomassie Blue. Autoradiography was carried out as with the $0.3 / 2 \%$ gels.

\section{Results}

Two distinct VIII:CAg populations in normal plasma. Normal plasma was gel filtered on $6 \%$ agarose and fractions assayed for VIII:C, VIII:CAg, and vWF antigen (Fig. $1 A$ ). Almost all vWF antigen was present in the $V_{0}$ peak, while VIII:CAg was present both in the $V_{0}$ peak and in a $V_{i}$ position near that of fibrinogen. The $V_{i}$ VIII:CAg comprised 15\% of the total recovered VIII:CAg measured by fluid-phase immunoradiometric assay.

VIII;C activity in the $\mathrm{V}_{0}$ region was approximately twice that predicted from the VIII:CAg level. This may reflect VIII:C activation during chromatography or a difference in the precipitating properties of VIII:CAg present in the $\mathrm{V}_{0}$ region vs. that in whole plasma used to prepare the standard curve for VIII:CAg determination. No VIII:C activity was observed in the $V_{i}$ eluate fractions. This was true even when eluate fractions containing 0.01-0.03 U/ml VIII:CAg (levels corresponding to the lower limits of VIII:C activity detectable in whole plasma) were concentrated to as much as $0.6 \mathrm{U} / \mathrm{ml} \mathrm{VIII}: \mathrm{CAg}$.

Although immunoreactive material was present at the $V_{i}$ position, the absence of VIII:C activity raised the possibility that the antigen might not be related to VIII:C. This could occur if ${ }^{125} \mathrm{I}-\mathrm{Fab}$, used to detect VIII:CAg, was nonspecific.

To provide a functional correlation of the $\mathrm{V}_{i}$ antigenic material with VIII:C, inhibitor blocking experiments were performed (16) based on the ability of Fab to neutralize VIII:C activity (Table I). A sample of plasma, incubated for $2 \mathrm{~h}$ with Fab, lost $50 \%$ of its original VIII:C activity. This inhibitory activity was eliminated by incubating Fab with $V_{i}$ VIII:CAg fraction before the addition of Fab to plasma. Thus, the $V_{i}$ antigen has an antibody binding region similar to that responsible for VIII:C activity. When the $V_{i}$ fraction was incubated with
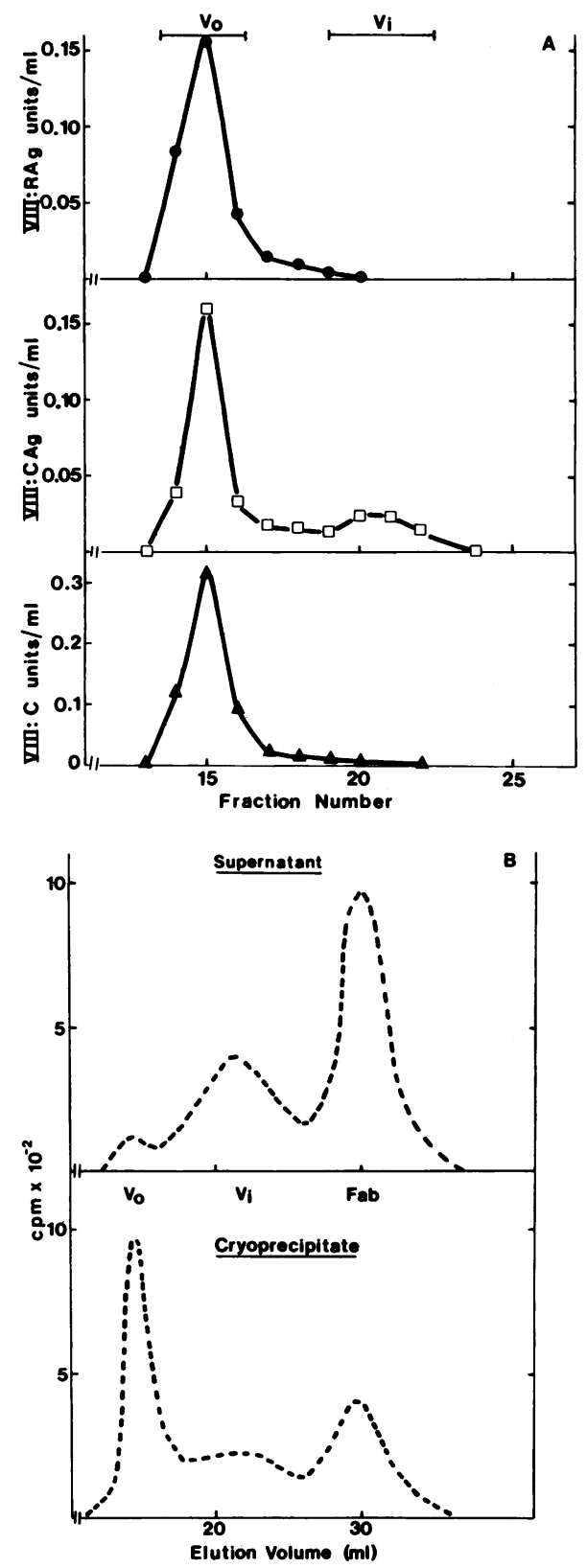

Figure 1. $(A)$ Elution profile of normal plasma chromatographed on Sepharose CL-6B and assayed for VWF antigen (VIII:RAg) (๑), VIII:CAg (口), and VIII:C ( $\Delta)$. VIII:CAg is primarily in $V_{0}$ and $V_{i}$ fractions. $(B)$ Gel filtration of cryosupernatant and cryoprecipitate, incubated with ${ }^{125} \mathrm{I}-\mathrm{Fab}$, and chromatographed over Sepharose CL6B. Complexes of ${ }^{125} \mathrm{I}-\mathrm{Fab}-\mathrm{VIII}: \mathrm{CAg}$ are in the $\mathrm{V}_{0}$ and $\mathrm{V}_{i}$ fractions. Unbound ${ }^{125} \mathrm{I}-\mathrm{Fab}$ is also present.

normal plasma, or added to normal plasma just before the reagents were mixed with hemophilic plasma plus calcium, clotting times were unaffected (see also Table I, line 5). 
Table I. Inhibition of Anti-VIII:C Fab by $V_{i}$ VIII:CAg

\begin{tabular}{llll}
\hline & \multicolumn{2}{c}{ Incubation time } & \\
\cline { 2 - 3 } Sample & Together & With plasma & $\begin{array}{l}\text { Percent VIII:C } \\
\text { remaining }\end{array}$ \\
\hline & $h$ & $h$ & $\%$ \\
Fab + buffer & 2 & 2 & 50 \\
Fab + buffer & 0 & 0 & 98 \\
Fab + V VIII:CAg & 2 & 2 & 92 \\
Fab + V VIII:CAg & 0 & 0 & 94 \\
V & 2 & 2 & 94 \\
buffer & 2 & 2 & 100
\end{tabular}

Anti-VIII:C Fab was incubated for $2 \mathrm{~h}, 37^{\circ} \mathrm{C}$ with buffer or $\mathrm{V}_{i}$ VIII:CAg. After a second incubation period of $2 \mathrm{~h}, 37^{\circ} \mathrm{C}$ with plasma, the VIII:C activity of the mixture was determined. Solutions were added just before initiation of the VIII:C assay with calcium for the zero incubation time.

Separation of VIII:CAg forms by cryoprecipitation. Analysis of cryosupernatant and cryoprecipitate (Fig. $1 B$ ) gave further evidence for two major VIII:CAg forms in plasma with different solubility properties. Samples of cryoprecipitate and cyrosupernatant were incubated with ${ }^{125} \mathrm{I}-\mathrm{Fab}$ and gel filtered over a Sepharose CL-6B column. Most $\mathrm{V}_{0}$ VIII:CAg was in the cryoprecipitate sample, while major amounts of $V_{i}$ VIII:CAg remained in the supernatant.

Electrophoretic separation of $V_{0}$ and $V_{i}$ VIII:CAg on agarose gels.In a more analytically useful procedure to detect $\mathrm{V}_{0}$ and $\mathrm{V}_{\mathrm{i}}$ VIII:CAg in whole plasma, ${ }^{125} \mathrm{I}$-Fab-treated plasma was electrophoresed into $0.3 / 2 \%$ agarose gels without SDS (Fig. 2). Interprotein ionic bonds are maintained in this system, while high and low molecular weight proteins can separate on the $2 \%$ agarose gel (even if they have similar isoelectric points). Placement of origin wells in the highly porous $0.3 \%$ agarose allowed high

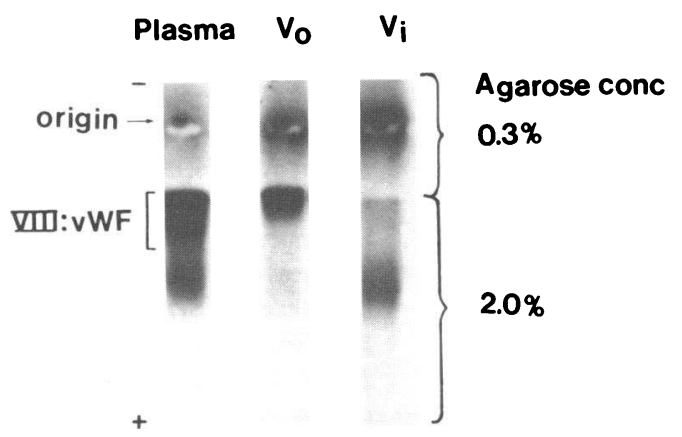

Figure 2. One-dimensional electrophoresis of plasma, $\mathrm{V}_{0}$ and $\mathrm{V}_{\mathrm{i}}$ gel filtration fractions that have been mixed with ${ }^{125} \mathrm{I}-\mathrm{Fab}$ and analyzed by autoradiography on $0.3 / 2 \%$ agarose gels. ${ }^{125} \mathrm{I}-\mathrm{Fab}-\mathrm{VIII}: \mathrm{CAg}$ in the $\mathrm{V}_{0}$ fraction is primarily at the gel interface. $\mathrm{V}_{i}{ }^{125} \mathrm{I}-\mathrm{Fab}-\mathrm{VIII}$ :CAg has greater anodal mobility. Both VIII:CAg forms are present in plasma. The position of vWF (brackets) was determined by crossed immunoelectrophoresis (not shown). molecular weight, negatively charged proteins to migrate out of the wells away from unbound, positively charged ${ }^{125} \mathrm{I}-\mathrm{Fab}$, which moved only slightly out of the well.

${ }^{125}$ I-Fab-VIII:CAg complexes in ${ }^{125}$ I-Fab-treated plasma were compared on these gels with ${ }^{125} \mathrm{I}-\mathrm{Fab}-\mathrm{VIII}: \mathrm{CAg}$ complexes present in $\mathrm{V}_{0}$ and $\mathrm{V}_{i}$ gel filtration fractions. ${ }^{125} \mathrm{I}-\mathrm{Fab}-\mathrm{V}_{i}$ VIII:CAg complex migrated farther toward the anode than ${ }^{125} \mathrm{I}-\mathrm{Fab}-\mathrm{V}_{0}$ VIII:CAg complex, and both forms were present in whole plasma.

$\mathrm{V}_{0}$ VIII:CAg was shown by immunoelectrophoresis (see Fig. 6 ) and ${ }^{125}$ I-anti-vWF overlay/autoradiography (18) to be associated with vWF protein. No evidence was obtained for a similar association of $V_{i}$ VIII:CAg with vWF, when plasma, separated on a $0.3 / 2 \%$ agarose gel, was electrophoresed into a second dimension gel containing anti-vWF IgG (data not shown).

No evidence of $V_{i}$ VIII:CAg binding to $v W F$ after gel filtration. $\mathrm{V}_{\mathrm{i}}$ VIII:CAg eluate $(0.1 \mathrm{U} / \mathrm{ml} \mathrm{VIII}: \mathrm{CAg}, 1 \mathrm{vol})$ was incubated for $2 \mathrm{~h}$ at $37^{\circ} \mathrm{C}$ with citrated hemophilic plasma (1 vol) containing <3\% VIII:CAg and <1\% VIII:C, in order to determine if $V_{i}$ VIII:CAg would bind to vWF protein (120\% vWF antigen). All $V_{i}$ VIII:CAg remained at the $V_{i}$ position both by gel filtration chromatography and by $0.3 / 2 \%$ agarose gel electrophoresis, indicating that persistent VIII:CAg-vWF complexes had not formed. These conditions are similar to those used by others (19) to show that calcium-dissociated VIII:C protein obtained from the $V_{0}$ fraction could rebind to $v W F$.

Since vWF in hemophilic plasma might lack the binding site for VIII:CAg, vWF from a normal individual was treated with $0.25 \mathrm{M} \mathrm{CaCl}_{2}$ to dissociate VIII:C and VIII:CAg. The $\mathrm{Ca}^{2+}$ treated vWF was then incubated with $\mathrm{V}_{\mathrm{i}}$ VIII:CAg (Fig. $3 \mathrm{~A}$ ) at $37^{\circ} \mathrm{C}$ with $3 \mathrm{mM} \mathrm{CaCl}$ and proteolytic inhibitors, followed by incubation with ${ }^{125} \mathrm{I}-\mathrm{Fab}$ and gel filtration. A low concentration of $\mathrm{CaCl}_{2}(3 \mathrm{mM})$ was included in these experiments because the binding of $\mathrm{Ca}^{2+}$-dissociated VIII:C to $\mathrm{Ca}^{2+}$-treated vWF and hemophilic vWF increases compared with gel filtration without calcium (20). The trace increase of radioactivity in the $\mathrm{V}_{0}$ shows that virtually no $\mathrm{V}_{\mathrm{i}}$ VIII:CAg bound to vWF.

As a control, $\mathrm{Ca}^{2+}$-dissociated VIII:C protein, obtained by gel filtration of VIII:C/vWF in $0.25 \mathrm{M} \mathrm{CaCl}_{2}$, was similarily incubated with $\mathrm{Ca}^{2+}$-treated vWF and ${ }^{125} \mathrm{I}-\mathrm{Fab}$, and gel filtered. In contrast with $\mathrm{V}_{\mathrm{i}}$ VIII:CAg, there was a significant increase in $\mathrm{Ca}^{2+}$-dissociated VIII:CAg eluting in the $\mathrm{V}_{0}$ with vWF (Fig. $3 \mathrm{~B})$.

Characterization of $V_{0}$ and $V_{i}$ VIII:CAg by SDS-PAAGE. To obtain apparent molecular weights of VIII:CAg dissociated from vWF, samples containing VIII:CAg were compared on SDS polyacrylamide agarose gels. After incubation with ${ }^{125} \mathrm{I}$ Fab, samples were electrophoresed and ${ }^{125} \mathrm{I}-\mathrm{Fab}-\mathrm{VIII}: \mathrm{CAg}$ complexes were detected by autoradiography. Apparent molecular weights reported here are those of the free VIII:CAg, rather than the antigen-antibody complex, and were calculated by subtracting the $5 \times 10^{4}$ apparent mol wt of ${ }^{125} \mathrm{I}$-Fab from that of the complex $(8,9)$. Molecular weight values are those determined from electrophoresis on $4 \%$ polyacrylamide- $0.5 \%$ agarose gels (4\% PAAGE). These gels gave better resolution of protein bands 


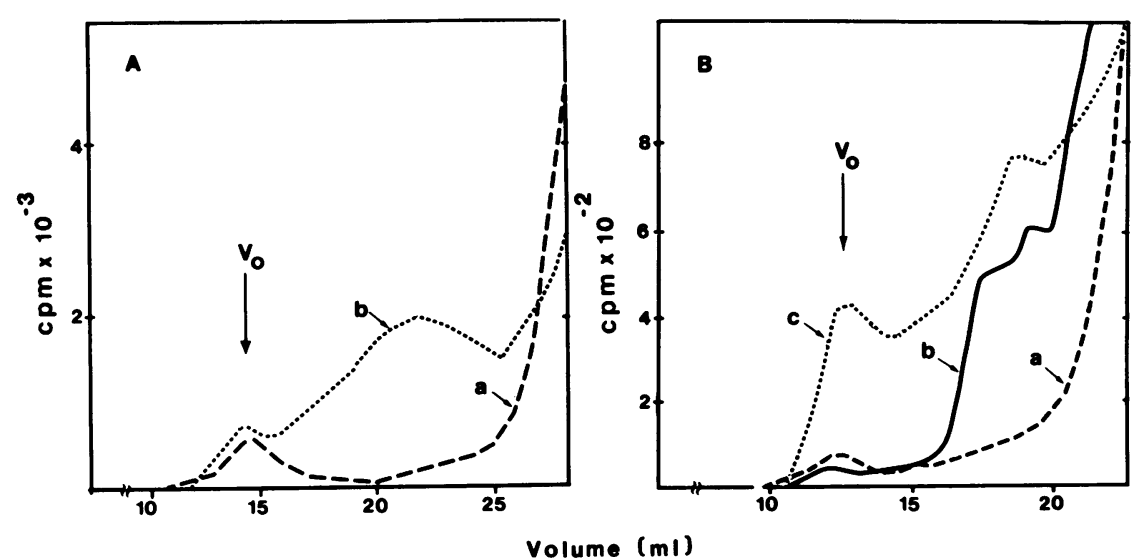

Figure 3. Gel filtration of $\mathrm{V}_{\mathrm{i}} \mathrm{VIII}: \mathrm{CAg}$ and $\mathrm{Ca}^{2+}$-dissociated $\mathrm{V}_{0}$ VIII:C protein with $\mathrm{Ca}^{2+}$ treated vWF. $(A) \mathrm{Ca}^{2+}$-treated vWF incubated with ${ }^{125} \mathrm{I}-\mathrm{Fab}$ was gel filtered over A5 $\mathrm{M}$ agarose $(a)$. Most ${ }^{125} \mathrm{I}-\mathrm{Fab}$ eluted as the free antibody (elution volume $>25 \mathrm{ml}$ ). When $\mathrm{V}_{i}$ VIII:CAg plus $\mathrm{Ca}^{2+}$-treated vWF, incubated with ${ }^{125}$ I-Fab, was gel filtered, no significant increase in radioactivity occurred in the $\mathrm{V}_{0}$ region $(b) .(B)$ In a similar experiment, but with a different preparation of $\mathrm{Ca}^{2+}$-treated vWF and a shorter agarose gel column, gel filtration of ${ }^{125} \mathrm{I}$-Fab plus $\mathrm{Ca}^{2+}$-treated vWF (a) or $\mathrm{Ca}^{2+}$ dissociated $\mathrm{V}_{0}$ VIII:C protein (b) produced little radioactivity in the $V_{0}$ region. $A$ 10-fold increase in $\mathrm{V}_{0}$ radioactivity resulted when all three proteins were incubated and chromatographed together $(c)$. and apparent mol wt values $10-15 \times 10^{3}$ lower than those obtained with $3 \%$ polyacrylamide- $0.5 \%$ agarose gels $(8,18)$ used previously.

The major VIII:CAg form in whole plasma was of mol wt $2.4 \times 10^{5}$ with other antigenic forms comprising $\sim 30 \%$ of the total by densitometry (Fig. 4). The $2.4 \times 10^{5}-\mathrm{mol}$ wt VIII:CAg form was also predominant in both $V_{0}$ and $V_{i}$ gel filtration fractions.

VIII:CAg in the $\mathrm{V}_{0}$ region was extremely susceptible to a process, most likely proteolysis, resulting in a lower molecular weight VIII:CAg form (Fig. 4). Gel filtration performed with (column 1) or without (column 2) careful preequilibration (Fig. 4) with fresh buffers containing inhibitors ( $\epsilon$-amino caproic acid, Trasylol, DFP, azide) and fresh or washed agarose yielded large quantities of $V_{0}$ VIII:CAg with a mol wt of $1 \times 10^{5}$.

VIII:C activity increased significantly with increasing amounts of the $1 \times 10^{5} \mathrm{~mol} \mathrm{wt}$ of VIII:CAg form. In two separate experiments when $50-60 \%$ of the total $V_{0}$ VIII:CAg was of mol wt $1 \times 10^{5}$, twice as much VIII:C activity was present in the $V_{0}$ peak compared with that measured when the same plasma samples were gel filtered with inhibitors and $70-80 \%$ of the total VIII:CAg was of mol wt $2.4 \times 10^{5}$. The inhibitors were sufficiently diluted in the VIII:C assay so as not by themselves to prolong the clotting time. $\mathrm{V}_{\mathrm{i}}$ VIII:CAg was less sensitive to degradation, since quantities of this $2.4 \times 10^{5}$-mol wt antigen remained constant in columns 1 and 2.

Effect of thrombin on $V_{0}$ and $V_{i}$ VIII:CAg examined by SDS4\% PAAGE. Thrombin-treated $\mathrm{V}_{0}$ and $\mathrm{V}_{i}$ VIII:CAg were examined on SDS-4\% PAAGE to detect molecular weight changes that might correspond to the appearance and inactivation of VIII:C activity.

Within $1 \mathrm{~min}$ after thrombin addition $(0.05 \mathrm{U} / \mathrm{ml}$ final concentration) to $\mathrm{V}_{0}$, the $1 \times 10^{5}$-mol wt VIII:CAg form became predominant, with concomitant loss of higher molecular weight antigens (Fig. 5). The $1 \times 10^{5}$-mol wt species slowly declined over $9 \mathrm{~min}$ at a rate proportional to the development of a broad major band, mol wt $0.8 \times 10^{5}$, and a minor band, mol wt 0.4 $\times 10^{5}$. After $15 \mathrm{~min}$ incubation with either 0.5 or $1 \mathrm{U} / \mathrm{ml}$ thrombin, most material was of mol wt $0.8 \times 10^{5}$. The width of the $0.8 \times 10^{5}$-mol wt band suggests that several antigenic forms of similar size were present.

The rise and fall of thrombin-generated VIII:C activity could be best fitted to the appearance and disappearance of the $1 \times 10^{5}$-mol wt band (Fig. $5 \mathrm{~B}$ ). However, the correspondence was not exact. At peak VIII:C activity ( $3 \mathrm{~min}$ ), both the 1 - and $0.8 \times 10^{5}$-mol wt bands were present in approximately equal proportions. Sampling at closer $(2 \mathrm{~min})$ time intervals gave the same result.

Thrombin activation experiments were also performed on column eluate fractions containing $V_{i}$ VIII:CAg $(0.07 \mathrm{U} / \mathrm{ml}$ VIII:CAg, $0.1 \mathrm{U} / \mathrm{ml}$ thrombin). The gel pattern was similar to that of $\mathrm{V}_{0}$ VIII:CAg with a loss of the $2.4 \times 10^{5}$-mol wt band and formation of the $1-$ and $0.8 \times 10^{5}$-mol wt bands. Low levels

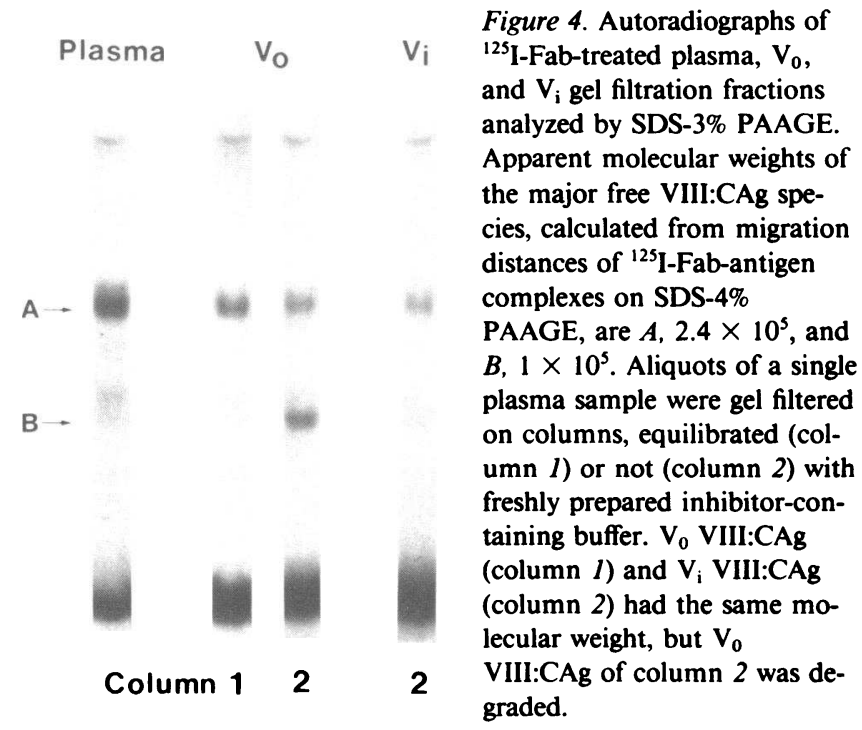



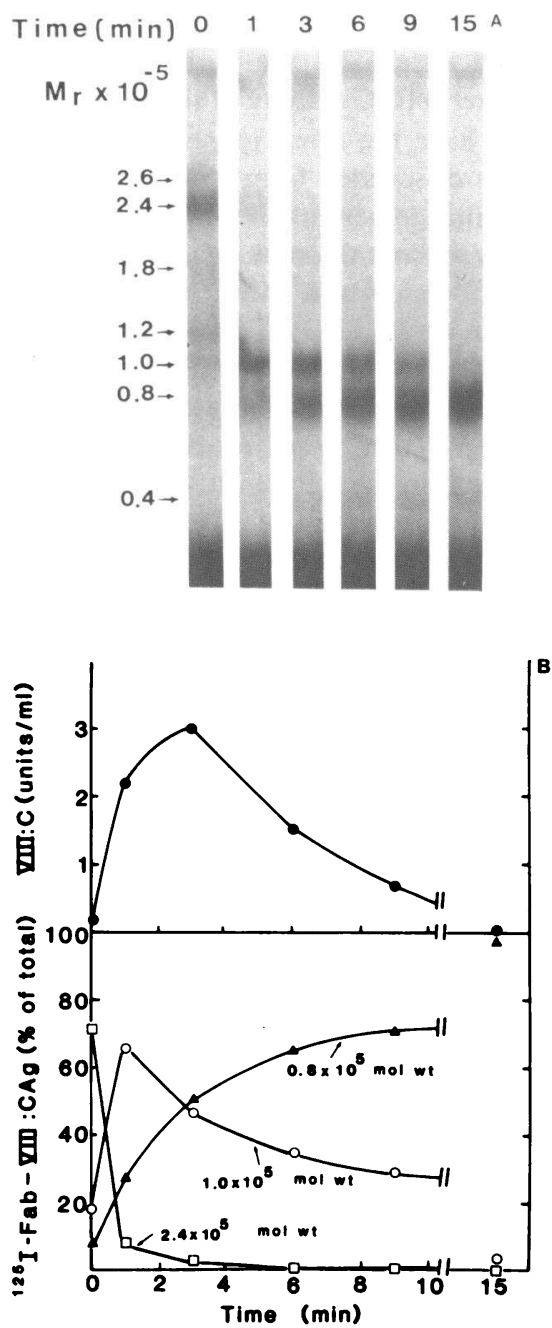

Figure 5. (A) Autoradiographs of thrombin-treated $\mathrm{V}_{0}$ VIII:CAg incubated with ${ }^{125}$ I-Fab and analyzed by SDS-4\% PAAGE. At the indicated times after thrombin addition $(0.05 \mathrm{U} / \mathrm{ml}$ final concentration) samples were withdrawn into ${ }^{125} \mathrm{I}$-Fab-DFP-hirudin solution. The sample applied to the last gel had been incubated for 15 min with $0.5 \mathrm{U} / \mathrm{ml}$ thrombin final concentration before the reaction was stopped by DFP-hirudin. Molecular weights are of the free VIII:CAg. (B) Thrombin activation of VIII:C in $\mathrm{V}_{0}$ fractions. Sample aliquots taken at the same time as those of electrophoresis were diluted 20fold and tested for VIII:C activity. Densitometric analysis of autoradiographs quantified the relative amounts of ${ }^{125}$ I-Fab-VIII:CAg.

of VIII:C activity were generated from an undetectable amount before thrombin addition to a peak of $0.04 \mathrm{VIII}: \mathrm{C} \mathrm{U} / \mathrm{ml}$ at 1 min, and 0.01 VIII:C U/ml after $9 \mathrm{~min}$.

Association of thrombin-activated $V_{0}$ VIII:CAg with vWF. To determine the relationship among thrombin-activated forms of VIII:CAg and vWF, $\mathrm{V}_{0}$ samples used above in the SDS- $4 \%$ PAAGE experiments were examined by one-dimensional immunoelectrophoresis in a nondenaturing system (Fig. 6).
Thrombin $(\mathrm{u} / \mathrm{ml})$

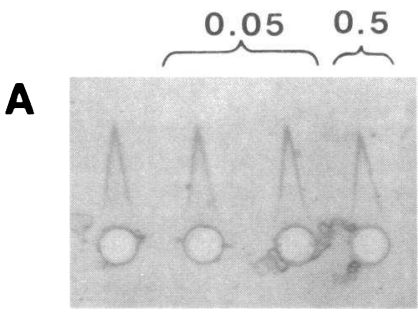

B

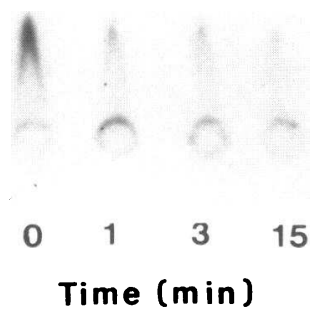

Figure 6. Immunoelectrophoresis of thrombin-treated $\mathrm{V}_{0}$ VIII:CAg incubated with ${ }^{125} \mathrm{I}$ Fab, and electrophoresed against rabbit anti-human VIII:RAg. At the indicated times after thrombin addition ( $0.05 \mathrm{U} / \mathrm{ml}$ final concentration), proteolysis was stopped with ${ }^{125}$ I-Fab-inhibitor-PEG solution. The last sample was incubated for $15 \mathrm{~min}$ with 0.5 $\mathrm{U} / \mathrm{ml}$ thrombin. Coomassie Blue-stained precipitin $\operatorname{arcs}(A)$ were autoradiographed $(B)$.
Thrombin-treated samples containing ${ }^{125}$ I-Fab were electrophoresed directly into a gel containing anti-VIII:RAg. After staining the gel with Coomassie Blue to observe the vWF precipitin arc, gels were autoradiographed to detect ${ }^{125} \mathrm{I}$-FabVIII:CAg bound to vWF.

Without thrombin (zero time), when most VIII:CAg was in the $2.4 \times 10^{5}$-mol wt form, ${ }^{125} \mathrm{I}-\mathrm{Fab}$ was maximally bound to the precipitin arc of vWF. $1 \mathrm{~min}$ after thrombin $(0.05 \mathrm{U} / \mathrm{ml})$, most VIII:CAg was in the $1 \times 10^{5}$-mol wt form, and less radioactivity was associated with VWF compared with the zerotime point. At $3 \mathrm{~min},{ }^{125} \mathrm{I}-\mathrm{Fab}$ associated with vWF declined by an additional $20 \%$ with respect to the 1-min sample, as estimated by densitometry. VIII:C activity was maximum at this time and approximately equal amounts of the 1- and 0.8 $\times 10^{5}$-mol wt VIII:CAg forms were present. Finally, after 15 min with $0.5 \mathrm{U} / \mathrm{ml}$ thrombin when little VIII:C activity was detectable and most VIII:CAg was of mol wt $8 \times 10^{4}$, only a trace of ${ }^{125} \mathrm{I}$-Fab-VIII:C Ag was bound to vWF. vWF protein was not altered by the thrombin treatment, as indicated by the invariant height of the precipitin arcs after exposure to thrombin for varying periods of time.

Accompanying the decrease in ${ }^{125} \mathrm{I}-\mathrm{Fab}$ bound to thrombintreated VIII:C/vWF, changes occurred in the electrophoretic mobility of ${ }^{125}$ I-Fab-VIII:CAg complexes on one-dimensional agarose gels. With no exposure to thrombin, most VIII:CAg of mol wt $2.4 \times 10^{5}$ migrated with vWF to position 1 (Fig. 7). After $1 \mathrm{~min}$ of exposure to $0.1 \mathrm{U} / \mathrm{ml}$ thrombin, at peak VIII:C activity when most VIII:CAg was in the 1 - and $0.8 \times 10^{5}-\mathrm{mol}$ wt forms, VIII:CAg was detected at position 1 and at the more cathodic position 2. When most VIII:CAg was of mol wt 0.8 $\times 10^{5}$, after $15 \mathrm{~min}$ of exposure to $1 \mathrm{U} / \mathrm{ml}$ thrombin, ${ }^{125} \mathrm{I}-\mathrm{Fab}-$ VIII:CAg migrated to position 2 and to the more anodic position 3. These data, along with the gel filtration studies, suggest that the 2.4- and $1 \times 10^{5}$-mol wt VIII:CAg antigen forms are pre- 
Thrombin $(\mathrm{U} / \mathrm{ml})$

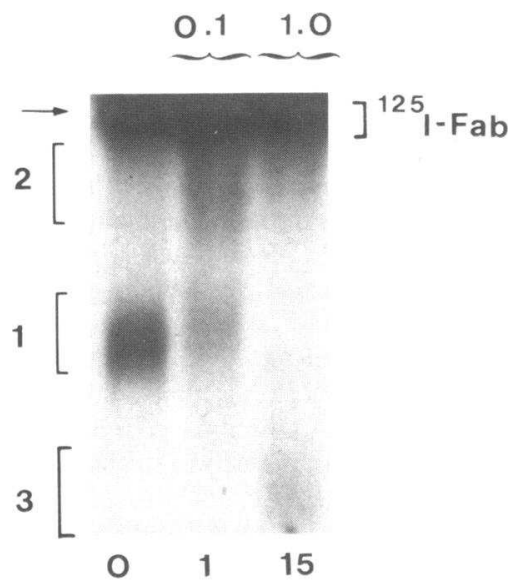

Time ( $\mathrm{min})$

Figure 7. Thrombin proteolysis of $\mathrm{V}_{0}$ VIII:CAg, analyzed by electrophoresis on $0.3 \%$ agarose gels. Samples of $V_{0}$ VIII:CAg were treated with $0.1(1 \mathrm{~min})$ and $1 \mathrm{U} / \mathrm{ml}$ thrombin $(15 \mathrm{~min})$ before the addition of ${ }^{125}$ I-Fab-inhibitor-PEG solution. The autoradiograph shows complexes of ${ }^{125} \mathrm{I}-\mathrm{Fab}-\mathrm{VIII}: \mathrm{CAg}$ at numbered positions and free ${ }^{125} \mathrm{I}-\mathrm{Fab}$ near origin wells (arrow). Without thrombin (zero time) most ${ }^{125}$ IFab-VIII:CAg was at position 1 associated with vWF (see Fig. 6). At peak VIII:C activity (1 min), antigen-antibody complexes were at positions 1 and 2. After $15 \mathrm{~min}$ of incubation with thrombin, most ${ }^{125} \mathrm{I}$ Fab-VIII:CAg was at positions 2 and 3.

dominantly associated with vWF, while the $8 \times 10^{4}$-mol wt VIII:CAg form is not bound to vWF.

\section{Discussion}

The two distinct populations of VIII:CAg that exist in normal human plasma are there regardless of the presence of anti-VIII:C antibody. In earlier studies Lazarchick and Hoyer (21) similarly found evidence for multiple forms of VIII:C-related protein in plasma, but hypothesized that these forms might arise from the antibody-induced dissociation of VIII:CAg from vWF.

Both antigenic populations have major forms, with a mol wt of $2.4 \times 10^{5}$, which indicates that $V_{i}$ VIII:CAg is not a proteolytic fragment derived from $V_{0}$ VIII:CAg. Only the $V_{0}$ VIII:CAg, which is associated with vWF, had VIII:C activity before thrombin exposure. The VIII:C activity measured in the standard clotting assay may reflect activated forms of VIII:C, (the $1 \times 10^{5}$-mol wt VIII:CAg ?) normally present in plasma in small quantities, associated with and stabilized by vWF (22, 23). The $2.4 \times 10^{5}$-mol wt VIII:CAg of both the $V_{0}$ and $V_{i}$ fractions might be procoagulant VIII:C forms that must undergo proteolysis before they can participate in coagulation reactions.
Alternatively, structural differences between the $2.4 \times 10^{5} \mathrm{~mol}$ wt $V_{0}$ and $V_{i}$ VIII:CAg, undetectable by present methods, could be responsible for the greater VIII:C activity of the $V_{0}$ protein.

$\mathrm{V}_{\mathrm{i}}$ VIII:CAg does not have the same properties as those reported for VIII:C protein dissociated from vWF by calcium $(8,19,24,25)$. The latter binds to hemophilic and $\mathrm{Ca}^{2+}$-treated vWF and has VIII:C activity without thrombin activation. While both $\mathrm{V}_{\mathrm{i}}$ VIII:CAg and $\mathrm{Ca}^{2+}$-dissociated VIII:C have approximately the same molecular weight, $2-3 \times 10^{5} \mathrm{~mol} \mathrm{wt}$ under nondenaturing conditions $(1,2,4,5), \mathrm{Ca}^{2+}$-dissociated VIII:C is primarily of mol wt $1 \times 10^{5}$ on SDS-PAGE and PAAGE (4, $8,24,25)$. This suggests that $V_{i}$ VIII:CAg protein is held together by covalent bonds not present in the calcium-treated material. It is not clear at present whether improvements in the purification of $\mathrm{Ca}^{2+}$-dissociated VIII:C protein, as by inclusion of large amounts of proteolytic inhibitors in all stages of preparation, will yield a major protein species with molecular weight characteristics of $\mathrm{V}_{i}$ VIII:CAg.

The finding that $V_{0}$ VIII:CAg binds to vWF, while $V_{i}$ VIII:CAg is unbound, has implications for the design of quantitative assays for VIII:CAg. Solid-phase immunoradiometric assays, which include reaction of test samples with heterologous anti-vWF protein (26) to quantify VIII:C, will not allow the detection of $V_{i}$ VIII:CAg. In addition, there are differences in the solubility of the two antigen forms that affect the quantitative fluid-phase assay. Ammonium sulfate (38\% saturation) used in fluid-phase immunoradiometric assay (13) was less effective than 38\% PEG-400 in precipitating ${ }^{125} \mathrm{I}-\mathrm{Fab}_{\mathrm{i}} \mathrm{V}_{\mathrm{i}}$ VIII:CAg (Weinstein, M., unpublished observations).

We found no single antigenic form whose appearance and disappearance correlated exactly with the thrombin-induced rise and fall in VIII:C activity. Although VIII:C activity increased simultaneously with the generation of the $1 \times 10^{5}-\mathrm{mol} \mathrm{wt}$ VIII:CAg fragment, peak activity was reached only when equal amounts of $1 \times 10^{5}$ and $8 \times 10^{4} \mathrm{VIII}: \mathrm{CAg}$ were present. When the multiple VIII:CAg forms comprising the broad band with mol wt of $8 \times 10^{4}$ were predominant, however, no VIII:C activity was detectable.

It has been suggested that VIII:C activity is fully expressed only when thrombin is in a complex with proteolyzed VIII:CAg $(27,28)$. The observed level of VIII:C activity might result from the combined rates of VIII:CAg activation, proteolytic or conformational (28) inactivation, and relatively slow thrombinVIII:CAg complex formation.

Alternatively, some active forms of the VIII:C protein may not be detected by the SDS-PAAGE gel method. In the intact $2.4 \times 10^{5}$-mol wt form of VIII:CAg, ${ }^{125}$ I-Fab blocks the ability of VIII:CAg to act as a cofactor. But upon activation, the peptide fragment containing the cofactor site might become separated from the antigenic site and thus not be visible by our gel procedures. There is evidence for the appearance of several nonimmunogenic fragments of purified VIII:C upon thrombin activation (8), but the correlation of one or more of these fragments with VIII:C activity is still speculative (29). 
Similarly, molecular weight alteration, too small to be seen by SDS-PAAGE, could yield major changes in the physical properties of VIII:CAg. For example, $V_{0}$ VIII:CAg treated with $1 \mathrm{U}$ of thrombin for 15 min produced a major antigenic form with mol wt $8 \times 10^{4}$ on SDS-PAAGE, but produced two antigenic forms of widely different electrophoretic mobility on one-dimensional agarose gel electrophoresis (Fig. 7).

$\mathrm{V}_{0}$ VIII:CAg association with vWF and changes induced by thrombin can be summarized as follows: The $2.4 \times 10^{5}-\mathrm{mol}$ wt $\mathrm{V}_{0}$ VIII:CAg form was initially bound to vWF; treatment with thrombin quickly produced VIII:CAg of $\sim 1 \times 10^{5} \mathrm{~mol}$ wt, a major portion of which was still associated with vWF accompanied by greater VIII:C activity; more prolonged digestion yielded inactive $0.8 \times 10^{5} \mathrm{~mol} w \mathrm{VIII}: \mathrm{CAg}$ no longer bound to vWF. The reduced association of the latter two antigen forms with vWF, compared with the $2.4 \times 10^{5}$-mol wt $V_{0}$ VIII:CAg, is in agreement with the observation of Davies et al. (30) on VIII:CAg binding to thrombin-treated vWF. As with $V_{i}$ VIII:CAg, this reduced binding of antigen to vWF could affect quantitative assays for VIII:C proteins and could be responsible for the commonly observed apparent reduction in VIII:CAg after thrombin treatment of plasma (31).

$V_{i}$ VIII:CAg undergoes the same reaction sequence with thrombin as $\mathrm{V}_{0}$ VIII:CAg to yield VIII:C activity. While the role of $\mathrm{V}_{\mathrm{i}} \mathrm{VIII}: \mathrm{CAg}$ in in vivo coagulation remains to be elucidated, it is a form of Factor VIII that does not depend on nonphysiological ionic strength conditions to act independently of vWF.

\section{Acknowledgments}

We thank Drs. Joel L. Moake and Daniel Deykin for their valued advice and support, and Ms. Stevelyn M. Diczok for expert secretarial assistance.

This work was supported by the Medical Research Service of the Veterans Administration and by National Heart, Lung and Blood Institute grant HL 22355.

\section{References}

1. Weiss, H. J., and S. Kochwa. 1970. Molecular forms of antihaemophilic globulin in plasma, cryoprecipitate and after thrombin activation. Br. J. Haematol. 18:89-100.

2. Owen, W. G., and R. H. Wagner. 1972. Antihemophilic factor: separation of an active fragment following dissociation by salts or detergents. Thromb. Diath. Haemorrh. 27:502-515.

3. Weiss, H. J., H. R. Baumgartner, T. B. Tschopp, V. T. Turitto, and D. Cohen. 1978. Correction by factor VIII of the impaired platelet adhesion to subendothelium in von Willebrand's disease. Blood. 51:267279.

4. Vehar, G. A., and E. W. Davie. 1980. Preparation and properties of bovine factor VIII (antihemophilic factor). Biochemistry. 19:401410.

5. Hoyer, L. W., and N. C. Trabold. 1981. The effect of thrombin on human factor VIII. Cleavage of the factor VIII procoagulant protein during activation. J. Lab. Clin. Med. 97:50-64.

6. Fulcher, C. A., and T. S. Zimmerman. 1982. Characterization of the human factor VIII procoagulant protein with a heterologous precipitating antibody. Proc. Natl. Acad. Sci. USA. 79:1648-1652.

7. Rapaport, S. I., S. Schiffman, M. J. Patch, and S. B. Ames. 1963. The importance of activation of antihemophilic globulin and proaccelerin by traces of thrombin in the generation of intrinsic prothrombinase activity. Blood. 21:221-236.

8. Weinstein, M. J., C. A. Fulcher, L. E. Chute, and T. S. Zimmerman. 1983. Apparent molecular weight of purified human factor VIII procoagulant protein compared with purified and plasma factor VIII procoagulant protein antigen. Blood. 62:1114-1117.

9. Weinstein, M. J., L. E. Chute, and D. Deykin. 1981. Analysis of factor VIII coagulant antigen in normal, thrombin-treated, and hemophilic plasma. Proc. Natl. Acad. Sci. USA. 78:5137-5141.

10. Rick, M. E., and L. W. Hoyer. 1973. Immunologic studies of antihemophilic factor (AHF, factor VIII). V. Immunologic properties of AHF subunits produced by salt dissociation. Blood. 42:737-747.

11. Weinstein, M., and D. Deykin. 1979. Comparison of factor VIIIrelated von Willebrand factor proteins prepared from human cryoprecipitate and factor VIII concentrate. Blood. 53:1095-1105.

12. Counts, R. B. 1975. Solid phase immunoradiometric assay of factor-VIII protein. Br. J. Haematol. 31:429-436.

13. Lazarchick, J., and L. W. Hoyer. 1978. Immunoradiometric measurement of the Factor VIII procoagulant antigen. J. Clin. Invest. 62:1048-1052.

14. Laura, R., D. J. Robison, and D. H. Bing. 1980. (p-Amidinophenyl) methanesulfonyl fluoride, an irreversible inhibitor of serine proteases. Biochemistry. 19:4859-4864.

15. Riordan, J. F., and B. L. Vallee. 1967. Reactions with $N$-ethylmaleimide and p-mercuribenzoate. Methods Enzymol. 11:541-548.

16. Zimmerman, T. S., L. de la Pointe, and T. S. Edgington. 1977. Interaction of Factor VIII antigen in hemophilic plasmas with human antibodies to Factor VIII. J. Clin. Invest. 59:984-989.

17. Laudano, A., and R. F. Doolittle. 1980. Studies on synthetic peptides that bind to fibrinogen and prevent fibrin polymerization. Structural requirements, number of binding sites, and species differences. Biochemistry. 19:1013-1019.

18. Moake, J. L., M. J. Weinstein, J. H. Troll, L. E. Chute, and N. M. Colannino. 1983. Direct radioimmune detection in human plasma of the association between factor VIII procoagulant protein and von Willebrand factor, and the interaction of von Willebrand factor-bound procoagulant VIII with platelets. Blood. 61:1163-1173.

19. Cooper, H. A., and R. H. Wagner. 1974. The defect in hemophilic and von Willebrand's disease plasmas studied by a recombination technique. J. Clin. Invest. 54:1093-1099.

20. Zucker, M. B., M. E. Soberano, A. J. Johnson, A. J. Fulton, S. Kowalski, and M. Adler. 1983. The in vitro association of antihemophilic factor and von Willebrand factor. Thromb. Res. 49:37-41.

21. Lazarchick, J., and L. Hoyer. 1977. The properties of immune complexes formed by human antibodies to Factor VIII. J. Clin. Invest. 60:1070-1079.

22. Switzer, M. E. P., S. V. Pizzo, and P. A. McKee. 1979. Is there a precursive, relatively procoagulant-inactive form of normal antihemophilic factor (Factor VIII)? Blood. 54:916-927.

23. Weiss, H. J., I. I. Sussman, and L. W. Hoyer. 1977. Stabilization of Factor VIII in plasma by the von Willebrand factor. J. Clin. Invest. 60:390-404.

24. Fulcher, C. A., and T. S. Zimmerman. 1982. Characterization of the human factor VIII procoagulant protein with a heterologous precipitating antibody. Proc. Natl. Acad. Sci. USA. 79:1648-1652. 
25. Fay, P. J., S. I. Chavin, D. Schroeder, F. E. Young, and V. J. Marder. 1982. Purification and characterization of a highly purified human factor VIII consisting of a single type of polypeptide chain. Proc. Natl. Acad. Sci. USA. 79:7200-7204.

26. Thomas, K. B., M. A. Howard, J. Koutts, and B. G. Firkin. 1981. A simplified immunoradioactive assay for human factor VIII coagulation antigen. Thromb. Haemostasis. 46:167. (Abstr.)

27. Hultin, M. B., and J. Jesty. 1981. The activation and inactivation of human factor VIII by thrombin: effect of inhibitors of thrombin. Blood. 57:476-482.

28. Switzer, M. E. P., and P. A. McKee. 1980. Reactions of thrombin with human factor VIII/von Willebrand factor protein. J. Biol. Chem. 255:10606-10611.
29. Fulcher, C. A., J. R. Roberts, and T. S. Zimmerman. 1983. Thrombin proteolysis of purified factor VIII procoagulant protein: correlation of activation with generation of a specific polypeptide. Blood. 61:807-811.

30. Davies, B. L., R. A. Furlong, and I. R. Peake. 1981. Studies on the relationship between factor VIII related antigen (VIII:RAg) and factor VIII clotting antigen (VIII:CAg) by immunoelectrophoresis and autoradiography using ${ }^{125}$ I-anti VIII:CAg. Thromb. Res. 22:87-96.

31. Rotblat, F., and E. G. D. Tuddenham. 1981. Immunologic studies of factor VIII coagulant activity (VIII:C) 1. Assays based on a haemophilic and an acquired antibody to VIII:C. Thromb. Res. 21:431-445. 